\title{
Salmonella Species Detection in Chicken Noodle Toppings Prepared by the Food Vendors around Jatinangor Campus of Universitas Padjadjaran
}

\author{
Luk Lee Zia, ${ }^{1}$ Imam Megantara, ${ }^{2}$ Suryosutanto ${ }^{3}$ \\ ${ }^{1}$ Faculty of Medicine Universitas Padjadjaran, ${ }^{2}$ Department of Microbiology Faculty of Medicine \\ Universitas Padjadjaran, ${ }^{3}$ Department of Pharmacology and Therapy Faculty of Medicine \\ Universitas Padjadjaran
}

\begin{abstract}
Background: Salmonellae is Gram negative Enterobacteriaceae which are commonly found in water. It can cause diseases in human through improper hygiene and sanitation practice, contamination of poultries, cross contamination from other food during storage, and also from Salmonella species carriers. Chicken noodle toppings are usually prepared early in the morning and not heated up upon serving. There are possibilities for bacterial contamination if the food vendors lack of hygienic practices. The risk of Salmonella species contamination is increased too as it can be spread through inappropriate hygiene and sanitation. Hence, the objective of the study was to detect the presence of Salmonella species in the chicken noodle toppings prepared by the food vendors around Jatinangor Campus of Universitas Padjadjaran.

Methods: A descriptive laboratory study was conducted in September 2013. A total of 44 samples of chicken noodle toppings were collected from the food vendors in Jatinangor. The samples were cultured on Salmonella-Shigella agars. Then, Gram staining and biochemical tests were performed.

Results: The chicken noodle toppings were not contaminated by Salmonella species, but other bacteria species such as Klebsiella pneumoniae, Serratia, Enterobacter, Escherichia coli, and Shigella species were found.

Conclusions: There is no Salmonella species found. However, there are some other bacteria found such as Klebsiella pneumoniae, Serratia, Enterobacter, Escherichia coli, and Shigella species. It means that the food vendors lack of hygienic and sanitation aspects. Thus, proper actions should be taken to educate and increase the awareness of food vendors on the importance of sanitation. [AM].2016;3(4):566-9]
\end{abstract}

Keywords: Chicken noodle toppings, salmonellae contamination, Salmonella species

\section{Introduction}

Salmonellosis is still frequently reported and always be a public health concern. Food hygiene and sanitation are important in avoiding food borne disease in human beings. According to Indonesian Food and Drug Regulatory Agency, there are previous studies proved that the food safety condition is still below standard in Indonesia. Approximately, $43 \%$ of food poisoning cases are frequently caused by street food and catering services. ${ }^{1}$ Moreover, according to the study conducted in Bogor, Indonesia, by Kusumaningrum et $\mathrm{al}^{2}, 24.8 \%$ of food products examined are contaminated by Salmonella species in open markets and supermarkets. Besides, the incidence of typhoid fever in children aged less than 5 years old is quite high as reported by Department of Child Health of Dr. Hasan Sadikin General Hospital, Bandung. ${ }^{3}$ This shows that Salmonellae contamination is still a major problem.

Majority of Salmonella species are pathogenic in human beings. Improper hygiene and sanitation can cause Salmonellosis. Moreover, contamination of poultries, cross contamination from other food during storage time, and Salmonella species carriers are also the factors that cause Salmonellosis. ${ }^{4-6}$ The timeline from the preparation of chicken noodle toppings until they are being served has an increase risk of bacterial contamination. If the food handling practice by the food vendors is improper, the risk of Salmonellae

Correspondence: Luk Lee Zia, Faculty of Medicine, Universitas Padjadjaran, Jalan Raya Bandung-Sumedang Km.21, Jatinangor, Sumedang, Indonesia, Phone: +6285624609711 Email: luklz@live.com.my 
contamination would increase. Therefore, this study was conducted to detect the presence of Salmonella species in the chicken noodle toppings prepared by the food vendors around Jatinangor Campus of Universitas Padjadjaran.

\section{Methods}

This descriptive laboratory study was approved by Health Research Ethics Committee Faculty of Medicine Universitas Padjadjaran. Total sampling was used to collect the samples. The samples used for this study were the chicken noodle toppings prepared by the food vendors around Jatinangor Campus of Universitas Padjadjaran. The samples were collected from shops and mobile food vendors selling chicken noodles in September 2013. Sellers with proper lights and electricity, tables and chairs, proper water source to wash plates and glasses were classified as shops, while sellers with food at roadside with no proper water source to clean the plates and glasses were classified as mobile food vendors.

In this study, one sample was taken from each shop and mobile food vendors around lunch time (12.00-13.00). The samples were collected in clean plastic pockets. The study was conducted for three times. The inclusion criteria were fresh chicken noodle toppings that were taken straight from the place where the food vendors kept them, and shops that agreed to sell or give small amount of chicken noodle toppings. The exclusion criterion was the chicken noodle topping that was already put on the noodles. The study variable was the presence of Salmonella species in the chicken noodle toppings prepared by the food vendors. The samples of this study were immediately transported to the Microbiology Laboratory at Faculty of Medicine Universitas Padjadjaran. At the Microbiology Laboratory, the samples were transferred from the plastic pockets into the Trypticase Soy broth (TSB) (3 ml) in a test tube left for 24 hours in $37^{\circ} \mathrm{C}$ incubator. On the next day, an inoculating loop was used to take the samples and then streaked on the Salmonella-Shigella (SS) agars. The culture medias were then incubated $\left(37^{\circ} \mathrm{C}\right)$ for 24 hours and observed for colonies growth after 24 hours. On the following day, Gram staining and biochemical tests were performed to identify the organisms that grew on the SS agars.

Moreover, the interview were performed to obtain the factors that can cause Salmonellae contamination from each food vendor. It included the water sources used for cooking,
Table Identification of Bacteria from the Colonies of Chicken Noodle Toppings

\begin{tabular}{lc}
\hline \multicolumn{1}{c}{ Bacteria } & Samples \\
\hline Salmonella species & 0 \\
Klebsiella pneumoniae & 5 \\
Serratia species & 3 \\
Enterobacter & 3 \\
Escherichia coli & 1 \\
Shigella species & 1 \\
\hline
\end{tabular}

typhoid fever history of the cook, and also the ways of food handling, such as, washing hands before cooking, the use of gloves during cooking, and also the method of keeping and heating up the leftover chicken noodle toppings and the location to buy raw chicken.

\section{Results}

This study showed that there was no Salmonella species found, but discovered other different types of organisms (Table 1).

Moreover, the presence of bacteria in the samples of chicken noodle toppings prepared by shops and mobile food vendors were then compared. The percentage of positive bacterial growth and negative bacterial growth on SS agars for shops were $35.1 \%$ and $64.9 \%$ respectively. While for mobile food vendors, there was no positive growth of bacteria on SS agars.

The information obtained from the surveys was interpreted. There were only 14 shops which underwent the interview and got two missing data. It showed that most of the shops used underground water to cook and followed by water from pump and mineral water (Aqua ${ }^{\circledR}$ ). Among the food vendors, 12 of them never got typhoid fever and two of them did not know. All of the food vendors washed hands before cooking and only four of them used hand gloves during food handling. According to the information obtained, the food vendors kept the leftover chicken noodle toppings covered in freezers and also in fridge and all of them heated up the chicken noodle toppings until boiling point. Most of them bought the raw chickens from market and some from the supplier.

\section{Discussions}

There was no Salmonella species found in the 
chicken noodle toppings. This may be because the water source was not contaminated by Salmonella species. Besides, there was no food handler who was previously infected by Salmonella species which would result in becoming a carrier. On the other hand, there was no cross contamination of Salmonella species from other food sources during storage time.

However, other bacteria such as Klebsiella pneumoniae (K. pneumoniae), Serratia, Enterobacter, Escherichia coli (E. coli), and Shigella species were found. All of the bacteria found were from the Enterobacteriaceae family. This can be due to improper food handling by the food vendors. Moreover, it could also because the water sources used were contaminated by those bacteria.

The results showed that K. pneumoniae was found in most of the samples, but, it cannot be concluded that $K$. pneumoniae was the most abundant bacteria found in the chicken noodle shops in Jatinangor. This was because it did not represent the condition that it should be and the bacteria did not culture according to standard agars to confirm the actual situation since the study objective was to find Salmonella species only. Hence, only SS agars were used to culture.

The $K$. pneumoniae is a natural enteric flora in normal humans. It can cause bacterial pneumonia which is about 1\%. If it exists in a huge quantity, it can cause diseases such as extensive hemorrhagic consolidation of lungs, urinary tract infections, and bacteremia with focal lesions in debilitated patients. Klebsiella usually causes nosocomial infections. ${ }^{7}$ This organism is often transmitted through body contacting with the water supply especially during bathing, eating, or poor hygiene. Klebsiella has an infective dose of 3.5-7.9×105 cells $/ \mathrm{ml}$. Hence, a susceptible individual who consumes $3.5 \times 105$ Klebsiella per ml of 100 ml drinking water will be at risk of getting infection. ${ }^{8}$

Serratia sp. is a saprophytic organism which is commonly found in humans and animals intestinal tracts, and also in the environment, especially in water sources. ${ }^{9}$ At the present time, most commonly Serratia marcescens is known as opportunistic pathogens which cause hospital-acquired infections such as bacteremia, pneumonia, wound and urinary tract infections. It usually infects respiratory tracts and genitourinary tracts of human being. The risk factors of getting infected by Serratia marcescens are unhygienic infection control practice by the health care workers, catheterization of hospitalized patients, exposure to contaminated substances, and also increased antibiotic usage in compromised human. ${ }^{10}$

The next bacteria found were Enterobacter $s p$.. They are normal inhabitants found in water and soil. They are also free-living organisms in the intestinal tracts of humans and animals. These organisms are often associated with opportunistic and hospital acquired infections. ${ }^{9}$ They can produce diseases such as sepsis and urinary tract infections. ${ }^{7}$

The E. coli is a normal flora found in the intestine tract of human. The organism does not produce disease unless it reaches the tissues outside the intestinal tract or the parts which have lesser common normal flora. $E$. coli can cause urinary tract infections, E.coli-associated diarrheal disease, sepsis and meningitis. ${ }^{7}$ According to World Health Organization (WHO) in guidelines for drinkingwater quality, this organism is used as fecal contamination indicator for enteric bacterial pathogens. The infective dose of $E$. coli can be lesser than 100 organisms. As stated in the guideline values for verification of microbial quality, E. coli should not be detectable in any $100 \mathrm{ml}$ samples from all water that are directly intended for drinking, treated water entering as well as in the distribution system. ${ }^{11}$ Since this organism was found in the food sample, this showed that the food has a recent contamination from fecal. If people consumed this food, they will have a chance to get infected. However, the strain of $E$. coli found cannot be determined because no further test has been conducted.

Furthermore, Shigella species was found in this study. This showed that it was quite harmful since this organism is highly communicable. The natural habitat of Shigella species is limited to the gastrointestinal tract. It is transmitted from an individual to another through feces, contaminated food, unhygienic practice, and flies. The infective dose for Shigella species is relatively low, that is 103 organisms. Shigella dysenteriae can cause severe disease such as dysentery. ${ }^{7}$ This bacteria can be found may be due to improper hygiene and sanitation during food preparation by the food vendors.

The presence of bacteria in the samples of chicken noodle toppings prepared by shops and mobile food vendors were then compared. It showed that there was no positive bacterial growth on SS agars for the mobile food vendors while there was $35.1 \%$ of positive bacterial growth on SS agars for shops. However, it cannot be concluded that the mobile food 
vendors' food was cleaner as there was no confirmation test being performed.

The results showed that the shops had more bacterial contamination. This may be because they were contaminated from the objects which had a contact with the chicken noodle toppings, for example, the forks and spoons, and also the chop sticks. In order to reduce the risk of getting bacterial contamination, clean wooden chop sticks are recommended to use. It is only used once and being discarded afterwards. Furthermore, the utensils were recommended to be rinsed with boiling water before they were being used. The results showed that the mobile food vendors were not contaminated by bacteria. This may be because the way of food handling by particular mobile food vendors were really up to standard. However, this did not reflect the real situation as the number of mobile food vendors were limited during the period of the study being conducted.

There were some limitations in this study. First, there was no direct observation of the way chicken noodle toppings prepared. Moreover, the numbers of mobile food vendors were limited in Jatinangor and there was also a limitation of time in conducting this study.

In conclusion, no Salmonella species were found in the chicken noodle toppings prepared by the food vendors around Jatinangor Campus of Universitas Padjadjaran. However, other bacteria species such as K. pneumoniae, Serratia, Enterobacter, E. coli, and Shigella species were found.

The government should monitor the food vendors from time to time and spontaneously on their hygiene practices and the way of food handling. This suggestion is to increase the awareness of the food vendors on the importance of hygiene and sanitation. Therefore, they will keep up the standard of cleanliness and hygiene on food preparation process. It is recommended that a further study should be conducted by directly observing the way chicken noodle toppings prepared. Moreover, the number of samples from mobile food vendors and also the time to conduct the study should be increased. This would provide more significant results on food contamination by Salmonella species.

\section{References}

1. Mariana RR, Santoso I, Wignyanto BS. The situation analysis of food safety to formulate policy of food safety opertional for food street vendors in Malang, Indonesia. J Agric Food Tech. 2011;1(10):194-9.

2. Kusumaningrum $\mathrm{H}$, Dewanti-Hariyadi R. Multidrug resistance among different serotypes of Salmonella isolates from fresh products in Indonesia. International Food Research Journal. 2012;19(1):57-63.

3. Setiabudi D, Madiapermana K. Demam tifoid pada anak usia di bawah 5 tahun di Bagian Ilmu Kesehatan Anak RS Hasan Sadikin, Bandung. Sari Pediatri. 2005;7(1):9-14.

4. Vandeplas S, Dubois Dauphin R, Beckers Y, Thonart P, Thewis A. Salmonella in chicken: current and developing strategies to reduce contamination at farm level. J Food Prot. 2010;73(4):774-85.

5. Monack DM. Salmonella: persistence and transmission strategies. Curr Opin Microbiol. 2012;15(1):100-7.

6. Podolak R, Enache E, Stone W, Black DG, Elliott PH. Sources and risk factors for contamination, survival, persistence, and heat resistance of Salmonella in low-moisture foods. J Food Prot. 2010;73(10):1919-36.

7. Brooks G, Carroll KC. Bacteriology. In: Malley J, Lebowiz H, editors. 2007 jawetz, melnick, \& adelberg's medical microbiology. 24, $4^{\text {th }}$ ed. New York: McGrawHill Companies, Incorporated; 2007. p. 253-56

8. Percival S, Embrey M, Hunter P, Chalmers R, Sellwood J, Wyn-Jones P. Microbiology of waterborne diseases: microbiological aspects and risks. 1st ed. Oxford: Elsevier Science; 2004. p. 136

9. Walker KE, Horneman AJ, Mahon CR, Manuselis G. Enterobacteriaceae. In: Wurm-Cutter E, editor. 2011 textbook of diagnostic microbiology. 4th ed. Philadelphia: Saunders W B Company; 2011.p. 435

10. Mahlen SD. Serratia infections: from military experiments to current practice. Clin Microbiol Rev. 2011;24(4):755-91.

11. WHO.Guidelines for drinking-waterquality. Geneva; 2011. [cited 2013 December 24]. Available from: http://whqlibdoc.who. int/publications/2011/9789241548151_ eng.pdf. 